\title{
Integration of Resources and Capabilities to Implement CRM: Case of Cooperative Development Bank
}

\author{
Alireza Shahraki ${ }^{1},{ }^{*}$ Fatemeh Kaveh ${ }^{2}$, Samira khaniki ${ }^{2}$ \\ ${ }^{1}$ Universityof Sistan and Baluchestan, Zahedan, I. R. Iran \\ ${ }^{2}$ University of Tehran, I. R. Iran \\ *f_kaveh@ent.ut.ac.ir
}

\begin{abstract}
In the past few years, due to various economic, social, and state banking system problems and above all, increasing the demand on supply, country's banks have always ignored customer orientation and its pillars, and have not been able to utilize modern marketing. This complete and comprehensive study, which has been developed chronologically, refers to this fact that although basic resources and capabilities such as information resources, analytical ability and operational capacity may affect on maintenance and protection process of under control properties, they are not sufficient to achieve desired performance in terms of acquisition and development of customers' relationships. In this study, Cooperative Development Bank (CDB) confirms that customer's satisfaction must be considered as a vital prerequisite for both acquisition and development processes of successful relationships for each company (both of them entail employees with relatively more familiarity with customers). Therefore, this paper emphasize on significance of trilateral resources and capabilities including technology, process and individual to implement an organizational CRM strategy successfully.
\end{abstract}

Keywords: CRM, Resources and Capabilities, Employee Satisfaction, Cooperative Development Bank (CDB)

\section{Introduction}

Customer relationship management (CRM) is a broadly recognized technique, which has been defined and evolved in association with development of information and communication technology as an important approach in business aiming at returning to individual marketing in 1990's. Changing customers' behaviors in financial and service institutions, particularly banks, is more sensitive because of their monetary-based activities and entails a precise and on-time planning by managers of banking and service network. Today, banking flow is confined to observe itself in a mirror named customer, to understand demands and inclinations of its customers in a competitive environment, and to satisfy its customers overwhelmingly. In the current marketing situation, losing a customer is terminated at the expense of losing interests, which would be required by that customer during his life so it is a warning for the bank. Financial industry privatization, promotion of trade fields of international finance institutes, and various demands of customers have created an intense competition in banking industry (Peppard, 2000). Such intense competition made governmental banks to shift their resources and capabilities from product/service-oriented services and abilities to customer-oriented services and capabilities. CRM as a customer-oriented strategy relaying on IT has been employed by various companies including banks increasingly and several institutions conducted numerous investments on CRM (Bharadwaj et al., 1993; Pan et al., 2006; Peppard, 2000; Reinartz et al., 2004; Rigby and Ledingham, 2004; Xu et al., 2002). Like Wells Fargo and Royal Bank of Canada, which are well known for their successful CRM strategies Cooperative Development Bank (CDB) in Iran is one of the big players that have implemented their enterprise wide CRM successfully.

In early 2004, CDB was concerned about its state; because of decreasing interest rate resulted from interest of deposits and loans, infringement of banking trade regulations by other industries. It seems that organizational CRM (Reinartz et al., 2004), as a tool to integrate resources and capabilities for meeting customers' demands, was a salient commercial strategy in this critical stage. It assured the CDB to outgo competitors, to attract new customers and to maintain its current customers. In 2008, CDB took an acceptable rank in terms of profitability per customer in Iran. Result variation was an ambitious effort to redesign the whole CRM and individuals' relation with the new approach in a way that it was resulted in enhancement of customer contentment considerably. CDB measures and efforts are consisted of two main phases: 1) Integration of required main resources and capabilities for innovation in its commercial processes (2004 to 2007); 2) Integration of human resources and capabilities to complete its mission on an organization relied on CRM strategy (2008 to 2009). Although the former model consisting of 
integrated database, analytical capability and operational ability has prepared a strong base to conduct an organizational CRM, the latter one has brought about the culture to accept CRM, which was practicable only with basic resources and capabilities. Eventually, CRM was accepted as a trade paradigm, and not a certain technology or technique, in which people involvement was obligatory. Figure 1 shows CRM implementation schedule of CDB.

\section{Figure 1: The history of CRM implementation by Cooperative Development Bank}

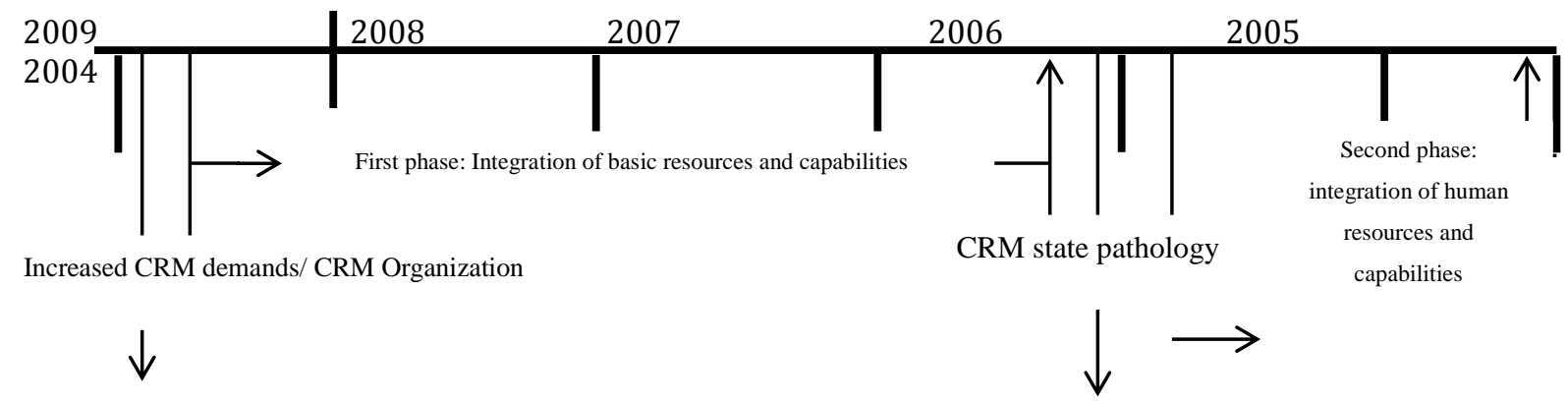

It shows the necessary resources and capabilities which must be imagined by companies for implementing CRM as an organizational trade strategy. We demonstrate the limitations of CRM implementation by using of integrated physical information systems through an empirical case while referring to this fact that considering human resources and capabilities must be stressed on CRM implementation process

Research review (Theoretical Background): The study is relied on resource-based view (RBV). The RBV theory has been taken as a substantial framework to estimate IT performance (Mata et al., 1995; Melville et al., 2004; Ray et al., 2005; Santhanam and Hartono, 2003). There are three main themes for estimating IT performance: 1) Resources heterogeneity (Grant, 1991). 2) Recourses unprovok ability and 3) Resources collection (Grant, 1991; Ray et al., 2005). Resources heterogeneity means that resource elements required for implementing IT-based strategies, including CRM, would be different concerning regions, industries and institutions. Moreover, it seems that resources unprovok ability and collection are related to CRM successful implementation. For instance, a competitor may try to copy your CRM innovation through purchasing and using similar CRM softwares and hardwares. Now this question is posed that whether their CRM performance rate is as similar as yours is. The answer is "No", because CRM of a company is not only consisted of tangible software and hardware but also it is composed of several intangible softwares and hardwares including individuals, process, organization and customerbased culture. Certainly, such intangible resources are inimitable and should be collected with other tangible resources to bring about a more stable compatibility for the company (Grant, 1991).

\section{Literature Review}

The common case amongst all RBV methods, outlined in IS literature, is a systematic framework to explain about useful capabilities and resources of a company for implementing and augmenting a successful IS. Given RBV and using integration of different researches in a regulated framework, Meliville et al. (Melville et al., 2004) offered a model based on IT commercial value. Their integrated model has been consisted of three various domains: 1) Focal company (across the company); 2) Competitive environment (across the industry); and 3) Macro environment (across the region of country). In this model, they emphasized on a fact that for creating value-generator processes a company must rely on not only IT resources such as technical and human resources but also it needs organizational complementary resources including culture, policies, regulations and non-IT human resources. Other RBV fundamental studies were agreed with Melville et al. For improving the IS of a company to a competence or capability (Melville et al., 2004). Peppard and Ward (2004) have observed that either commercial structure or process must be coordinated across the organization process to generate competence and capability from trade, technology and individual's inclination and behavior across the resources.

It is because that stating a certain competence, inclination, or capability in an organization is depended on using knowledge by all people, integration their knowledge, interaction with others and coordinating their acts (Peppard, 2004). Similarly, showed that an integrated system consisting of data, individuals and tools is a very effective and practical component for marketing decisions. Briefly, RBV prepares a 
balanced view of technology, process and individuals as critical components to implement "IS" successfully, which will result in a proper organizational performance alternatively. Amongst CRM related issues, using RBV as a direct theoretic principle is very rare; while the aforementioned trilateral method has been considered as the necessary condition for implementing CRM successfully. Table 1 represents required capabilities and critical resources to implement CRM in terms of discussed technology, process and individuals of RBV. For technology, commercial process and human resource Cooperative Development Bank have focused on information resource, analytical and operational abilities, customer satisfaction and customer-based activities respectively. During initial stages of CRM implementation, integrating information resources and analytical/operational abilities brought about a physical base to develop an organizational CRM strategy. However, they have found that CRM projects which underestimate human resources will not reach to organizational objectives because CRM is a commercial strategy originally which promote by individuals rather technology ( Chalmeta, 2006; Shum et al., 2008). Their secondary effort to involve people with CRM measures will fit them with a cultural incentive for internalization.

Table 1: Previous studies about key organizational capabilities and resources to implement CRM

\begin{tabular}{|c|c|c|}
\hline \multirow{5}{*}{$\begin{array}{l}\text { Sort } \\
\text { Technology }\end{array}$} & CRM capabilities resources & Showed by \\
\hline & $\begin{array}{l}\text { Customer's integrated } \\
\text { information IS/data quality }\end{array}$ & $\begin{array}{l}\text { (Fletcher and George, 1995), (Kulp et. Al; 2004), } \\
\text { (Meltzer, 2001), (Meyer and Kolbe, 2005), (Peppard, } \\
\text { 2000) }\end{array}$ \\
\hline & Width and depth of CRM & $\begin{array}{l}\text { (Rowley, 2002), (Rigby and Ledingham, 2004), (Reid } \\
\text { and Catterall, 2005), (Hwang and Kim, 2007), } \\
\text { (Fletcher and George, 1995). }\end{array}$ \\
\hline & applications & $\begin{array}{l}\text { (Teo et.al; 2006), (Rigby and Ledingham, 2004), } \\
\text { (Kohli et.al; 2001). }\end{array}$ \\
\hline & $\begin{array}{l}\text { Integration with remained } \\
\text { issues/ another IS }\end{array}$ & $\begin{array}{l}\text { (Meltzer, 2001), (Kohli et.al; 2001) (Fletcher and } \\
\text { George, 1995). }\end{array}$ \\
\hline \multirow[t]{4}{*}{$\begin{array}{l}\text { Commercial } \\
\text { process }\end{array}$} & Supporting customer's life cycle & $\begin{array}{l}\text { (Rowley, 2002), (Reinartz et.al; 2004), (Peppard, } \\
\text { 2000), (Verhoef, 2003). }\end{array}$ \\
\hline & Functional CRM process (plan, & (Winer, 2001), (Teo et.al; 2006), (Kim, 2006). \\
\hline & imple & $\begin{array}{l}\text { (Winer, 2001), (Teo et.al; 2006), (Kohli et.al; 2001), } \\
\text { (Kim and Lee, 2007). }\end{array}$ \\
\hline & $\begin{array}{l}\text { Decision making process CRM } \\
\text { performance estimation }\end{array}$ & $\begin{array}{l}\text { (Winer, 2001), (Kohli et.al; 2001), (Kim and Kim, } \\
\text { 2009). }\end{array}$ \\
\hline \multirow[t]{4}{*}{$\begin{array}{l}\text { Human } \\
\text { resources }\end{array}$} & Customer's satisfaction & $\begin{array}{l}\text { (Winer, 2001), (Kohli et.al; 2001), (Bendapudi and } \\
\text { Leone, 2002), (Donavan, Brown and Mowen, 2004). }\end{array}$ \\
\hline & Customer-based view & $\begin{array}{l}\text { (Winer, 2001), (Maxham and Netemeyer, 2003), (Kim } \\
\text { and Kim, 2009), (Donavan, Brown and Mowen, 2004). }\end{array}$ \\
\hline & Skills and experiences & $\begin{array}{l}\text { (Winer, 2001), (Reinartz et.al; 2004), (Kim and Kim, } \\
\text { 2009), (Fletcher and George, 1995), (Bendapudi and } \\
\text { Leone, 2002), }\end{array}$ \\
\hline & nt supports & $\begin{array}{l}\text { (Speier and Venkatesh, 2002), (Reinartz et.al; 2004), } \\
\text { (Kim and Kim 2009), (Fletcher and George, 1995) }\end{array}$ \\
\hline
\end{tabular}

\section{Methodology}

Such issues stimulated individualized necessities to request some nonchalant promotions. Since this state was in contradiction with eventual objective of CDB who sought for becoming a customer's knowledge based organization. CRM project of Cooperative Development Bank so called as CRM-T has consisted of two phases: First phase deals with integration of fundamental capabilities and resources and second one includes involvement of human capital within CRM strategy. Information resource, analytical and operational capabilities were fundamental capabilities and resources of CDB. Integrated customer information was a key factor to implement CRM successfully, which played as a supporter and had a great effect on knowledge base of customers of CDB. Although integration of the mentioned fundamental factors is not a tangible base for organizational CRM strategy, however integration of human resource is vital for improving it in main competence space of the organization. Nonetheless, CDB did not anticipate this mission in its initial CRM plan at first. Temporal findings showed that a main factor has been neglected in CRM implementation process certainly and it was individuals. In end 2007 when it has been 
tried to integrate human resources with their CRM strategy, CDB began to improve its employee premium system gradually, it changed roles and responsibilities of CRM occupations and reconstructed CRM trainings in order to use them in CRM personal competition. They started to integrate information resource, analytical and operational capability based on CRM knowledge due to case studies and other researches. CRM-T team started to analyzed related issues of data resources of CDB in 2004 and then formulated some instructions to improve these issues. CRM-T team worked with the selected employees in the framework of mid-practical teams for conditioning and taking necessary knowledge to support customer management processes.

Their widespread examinations and estimations illuminated that not only physical integration but also logic integration of all customer related data would be significant to prepare a proper understanding of customer for all channels. Given such findings, CRM-T team posed six various themes as main components of integrated data model. This redesigned integrated data model has been consisted of (1) customer, (2) products/services, (3) services management, (4) interactions management, (5) contract, and (6) interaction management. These themes, which include 15 to 24 detailed natures, are not physical but they are logic parts, which are connected to each other systematically. Concerning integrated information of ECDS, the following facilities were created for CDB:

- Detecting the most profitable and non-profitable customers optimally and practically.

- Improving customer management process through sharing adoptable thoughts of mid-practical teams about customer.

- Enhancing prosperity rate of marketing innovations via identification of effective critical events of company's interests.

- Meeting customers needs by offering an overview of customer to employees.

Case Study (A review on current field): Prior to implementing CDB's organizational CRM strategy, its informative systems were insufficient to manage customers relations based on IT architecture. Figure 2 represents CRM architectural model in 2003. CDB developed seven channels to communicate with customers and three official systems without any communication with customers including conducting financial affairs electronically, Strategic Information System (SIS), and account management system, which provided customers information for each channel. The information between such systems was being transferred using tubular line message queues in a fixed time. Previous version of databank was mainly composed of customer information including account management system, Marketing System (MKS) and some extracted databases and communicated with customer analysis databank somehow. Current CRM systems had numerous critical problems in terms of both technologic and strategic views. For technologic view, synchronizing obtained data from various channels and procuring necessary time to implement it were very arduous because each channel has its own sub-systems. Moreover, different data pattern of such heterogenic systems meant that integration and adoptability of customer's information would be secured rarely. Secondly, minor and separated analytical practices of each subsystem made additional targeting processes, which will result in insufficiency of marketing processes. Technical issues had negative effects on measures and efforts of customer management in turn. Those systems, which have been separated by channels, confined the CDB to sort out its customers in terms of their deposit value rather their incomes, interest, and then manage them in proportion to various products and channels. Since there were not any systematic ways or processes to control and manage such unique innovations, the issue was deteriorated, so planning and CRM implementation responsibilities were transferred to branches. It not only imposed additional workload on employees of branches but also created iterative and additional marketing efforts for similar customers by various branches. Eventually, it has led to increased marketing charges and decreased reaction rate, therefore employees considered CRM is not effective and practical.

\section{Results and Analysis}

Initial outcomes and learnt lessons: Taking CRM-T strategy increased customers' satisfaction rate, qualitative level of services, profitability, remained liabilities indicator and productivity, which in turn they have led to positive outcomes in operational applicability and bank financial performance. Before all, CRM-T prepared CRM commercial process setting opportunity in a way that more optimum and effective condition was resulted. For instance, in contrast with previous one-by-one marketing technique which was being directed non-systematically and was very expensive, the new designed process made possible standardization of related works as a set of demands, plans, implementations and examinations and then transferred planning and analysis to the central office and demand and implementation to operation 
department and branches. Project manager believed that organizational performance expense would experience a desired effect through minimizing turnover of each section or branch or removing ineffective operational elements such as iterative and additional works. At the same time CRM-T affected on organizational performances ideally. Figure 6 shows the achieved advancements in such affairs, its data belong to 2005 to 2007. Amongst carried out affairs for more optimum development and more productivity of bank, we discovered that customers' satisfactory level and services qualitative level have been escalated increasingly. Initially it was resulted from such fact that integrated customer management process will lead to improved customer satisfaction rate through CRM-T project. Most previous contests were derived from precedent segregated CRM. Moreover, customers' discontents were mainly due to changing previous marketing communication measures in which unilateral messages were far from customer's needs and then dispatched to unknown customers; however in the new model messages are prepared for certain individuals in custom and based on their current events automatically in correct and proper time.

Nevertheless, figure 6 includes another critical message. Although customers' contentment and enhancing qualitative level of services represent effect of customer maintenance activities, profitability, remained liabilities indicator and productivity, which represent acquiring new customers and development activities, do not show any noticeable development. How such situation is appeared? In the second half of 2007, we embarked to scrutinize this situation. A framework to estimate CRM performance was codified using CRM scorecard (Kim and Kim, 2009); seven infrastructural factors of CDB, which would affect on organizational CRM processes, were being analyzed. The quality is one of external services of the company (e.g. CRM process) which is influenced by quality of its internal services; on the other word, it is affected by infrastructural elements including CEO support, employee satisfaction, information technology etc (Heskett et al., 1994; Kim and Kim, 2009; Melville et al., 2004). Table 2 shows results of this study.

Figure 2: Performance indexes (2005-2007)

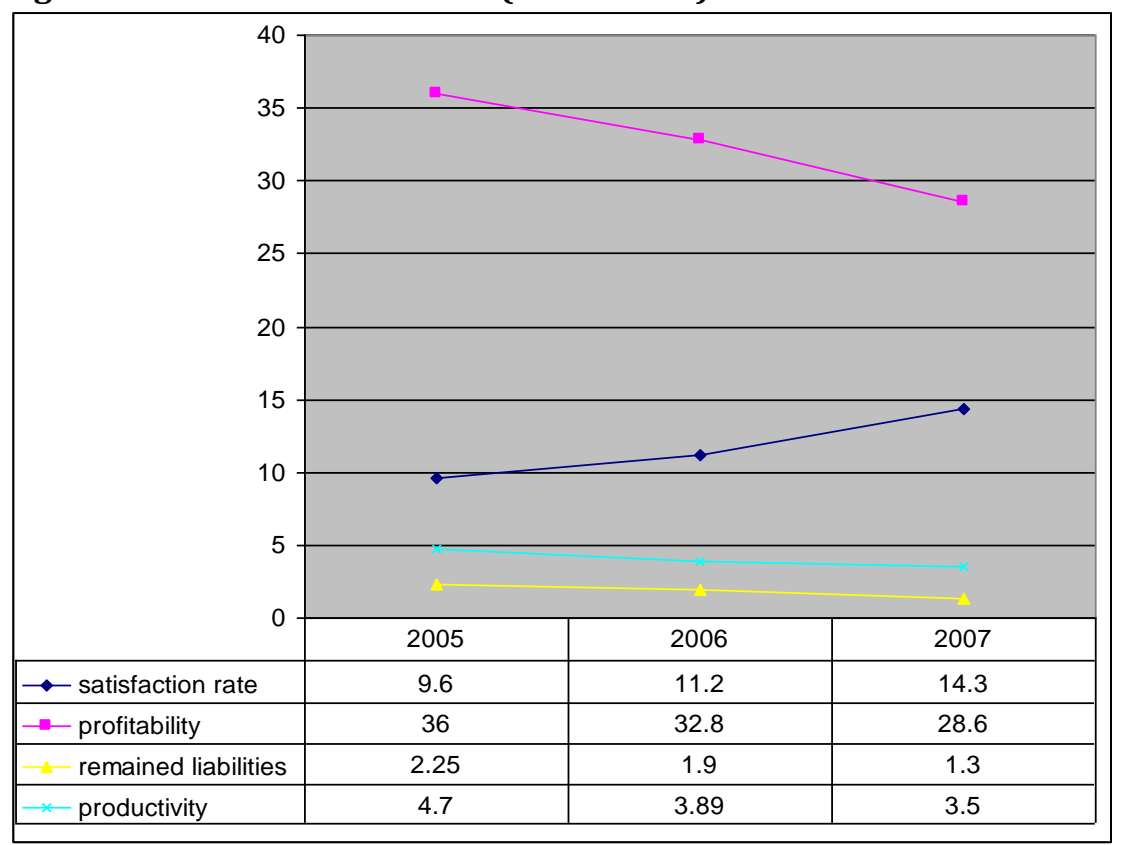

Table 2: The status of Fine-Equity Bank's CRM infrastructural factors

\begin{tabular}{llllllll}
\hline & OA & IT & EG & MO & PT & MA & ES \\
\hline Importance & 0.16 & 0.12 & 0.08 & 0.09 & 0.07 & 0.15 & 0.32 \\
Survey & 6.86 & 8.14 & 7.71 & 7.14 & 6.71 & 8.57 & 6.14 \\
KPI & 5.71 & 9.29 & N/A & 7.14 & 6.43 & N/A & N/A \\
Average & 6.29 & 8.71 & 7.71 & 7.14 & 6.57 & 8.57 & 6.14 \\
\hline
\end{tabular}

Note: OA: organizational alignment, IT: information technology, EG: explicit goal, MO: market orientation, PT: participation, MA: management attitude, ES: employee satisfaction (all figures were standardized in 10 scale). 
We conducted analytic hierarchy process (AHP) and Key Performance Indicator (KPI) for seven infrastructural elements and then standardized all numerical values, except importance score, in scale 10. Any score reflects the importance of a special value $(\lambda)$ which is calculated from comparison matrix of elements resulted from AHP (Wind and Saaty, 1980). As a result, although the view of higher management and IT were excellent for CRM, employee satisfaction and organizational alignment (i.e. CRM training/learning and adaptable premium system of CRM) were appeared very weakly. Interestingly, the customer satisfaction was the most important factor, which was approved by CRM related employees. It would be obstacle against voluntary participation at CRM activities through internalizing company's CRM strategy. Most CRM related studies about marketing and IS fields have concluded that increasing commitment of people via employee satisfaction is a key factor on CRM prosperity (for example, Bendapudi and Leone, 2002; Shum et al., 2008; Speier and Venkatesh, 2002). Moreover, acquisition and development of customer relations amongst three processes of CRM, acquisition, maintenance and customer development (Kim and Kim, 2009; Park and Kim, 2003; Reinartz et al., 2004) entail more personal affairs which is so called as customer orientation (Brown et al., 2002; Kim and Kim, 2009).Therefore, low employee satisfaction may be connected to weak acquisition and development process. Figure 6 shows CDB under the mentioned process. Such findings allow the bank to confirm this fact that they have lost another critical resource during CRM capabilities and resources integration process. Hence, they accelerated towards the second mission in order to complete CRM implementation through dealing with employee discontentment causes and solving them with systematic methods, which entails involving people in CRM affairs.

Employee Satisfaction (ES) and Customer Orientation (CO): Concerning technical viewpoint of CRM, CRM acceptance rate is depended on size of company (Luneborg and Nielsen, 2003). Luneborg and Nielsen (Luneborg and Nielsen, 2003), have claimed that conducting customer-oriented technology including CRM is easier for small to medium-sized banks rather big ones. Although the ratio of IT supporting affairs to whole company's tasks in small to intermediate banks is relatively high, a big element usually has several complicated organizational systems and structures by which IT supporting section is appeared very small. Therefore, a big bank would pose the CRM as a IS commercial strategy rather an information technology or a practical strategy. Whenever a company uses the CRM as a strategy, it will be obliged to involve its human resources in the strategy to achieve its final goals (Bendapudi and Leone, 2002; Kohli et al.; 2001; Winer, 2001) because various infrastructural elements may affect on view or behavior of employees and hence on quality of external commercial activity of the company (Donavan, 2004; etc Heskett et al.; 1994; Kim and Kim, 2009; Speier and Venkatesh, 2002). On the other word, individuals play as dealers amongst quality of internal services and quality of external services which is vital for Customer Relationship Management (Bendapudi and Leone, 2002; Kim and Kim, 2009; Melville et al.; 2004). Furthermore, experience has demonstrated that customer relations may be damaged in the case of absence of a key employee of relations department (Bendapudi and Leone, 2002). Recent studies have shown that companies should satisfy their employees who are internal customers of the company in fact (for example ., ( Donavan et al.; 2004; Kim and Kim, 2009; Kohli et al.; 2001; Reinartz et al.; 2004; Speier and Venkatesh, 2002).

In spite of importance of human resources, CDP underestimated this issue upon first stage of CRM implementation and it confined its CRM to a CRM that may be practical by functional developments. Our study revealed that discontentment of bank staff has been reflected in to separable parts. The first one was rejection of customers' knowledge sharing by private bankers. Although changing measures of customer management of private banks who manage assets of VIPs was one of the most important goals of CRM, they tried to keep their personal notes about customers details traditionally and though that why we should share our customers knowledge with others? It not only made impossible planning about CRM long-term strategy in terms of organizational view but also created a phenomenon called chain escapes in which escaping bankers may provoke escape of their under control customers. Another problematic situation was appeared by cashiers, as area of fire employees, who did not use of CRM system. Although the new system has embarked to prepare customized data about marketing opportunities and communicational messages of all customers for cashiers, they neither use such instructions nor turn on the system. They tried only to perform requests of customers who waited in lines quickly. Although this imitational pattern could interact with current operational jobs, it failed to understand sales potential opportunities and made CRM useless sometimes. After making a set of deep detailed interviews with front line employees, we found three suspected problems, which would effective on accepting innovations. First, all CRM-based premiums and salaries were not paid for the new marketing pattern. It meant that there was no difference amongst performance appraisals and attaching them to current 
marketing measure was not matter. Second, when employees conducted CRM innovations, an operational interference with a related department was unavoidable. Although CRM team encouraged employees to behave with customer in a way that he/she feels that they have only one customer and then identify his/her needs, CS team asked them to decline the average time for waiting in lines. Such parallel and contradict organizational structures annoyed employees and decreased their occupational satisfaction. Eventually, most employees felt that annoying and extensive behavior of new strategy has been prevalent across the company. Since the downstream method for CRM-T was considered as an imperative, selfish and tiresome policy, it prevented intentional internalization of CRM. In conclusion, for exploiting of all potentials of CRM-T, they should begin a new plan for integration of human resources and capabilities to solve the employees' discontentment.

Integration of human resources and capability: Since end 2007, the company sought after internalizing CRM-T strategy in deep side of the organization. Their efforts would be summarized as the follows: Improving its incentive and premium system, reorganizing roles and responsibilities of CRM occupations and preparing systematic learning and training plan. Such adaptable alignments with organizational CRM would be noticeable regulators for controlling organizational XRM strategy and its organizational performance (Reinartz et al.; 2004)

\section{Figure 3: Causes of employee dissatisfaction and its effects}

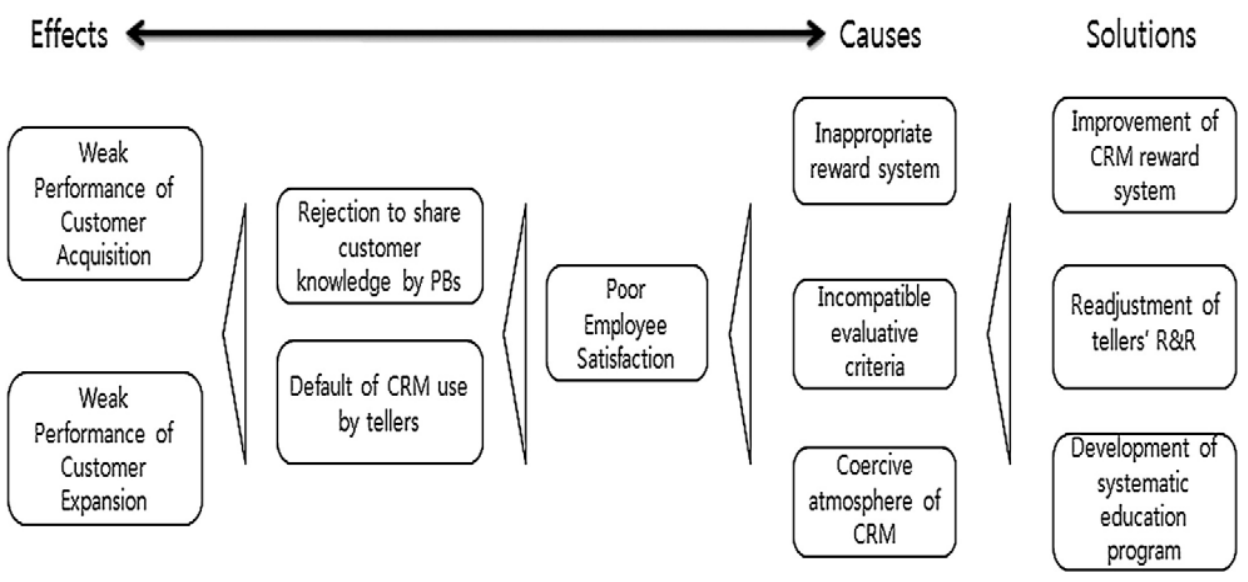

Developing proper premium patterns is a key factor to enable a company to affect on CRM strategy (Reinartz et al.; 2004).In order to develop a CRM adaptable premium system, CDB enhanced the previous incentive plan so called as "CR-Do". Although the previous plan appraised CRM activity rate and is behaved as an additional incentive, it failed to alter fundamental criteria if employees occupational performance appraisal. It meant that since incentives have been supplied by CR-Do s, they are not imperative for employees and they could not help to follow of system appraisal criteria which most them open were opposed with CRM philosophy. However, their CR-Do plan has been set for appraising the value, which is used by employees during their daily operations, and for appraising performance rate of employees. The second effort was moving towards a customer-based organizational structure. Reconstructing individuals' roles and responsibilities was unavoidable for offering differential products and consideration to different customers. In the same direction, CDB embarked to formulate several occupational limits. For example, the bank commissioned both its CRM and Cs teams separately to make appraisal criteria incompatible, i.e. CRM application usage and average interval to answer customers for employees of various branches. Therefore, if cashiers intend to develop their relations with customers or improve them the customer waiting time will increase and if they intend to meet demands of customers quickly to decrease waiting time it is impossible completely. This halved but incompatible criterion harmed employees satisfaction rate seriously. In order to solve this arduous state, the bank decided to integrate CRM team with marketing department in order to control both functions by a same department. Such structural change posed a new official base. According to this new base, although low-ranking cashiers, who interact with customers, are obliged to employ CRM system, their high-ranking counterparts who manage banking routine duties are free from referring to this system. On the other word, since they are allowed to examine the defined role and responsibility necessarily, being dumbfounded is unnecessary. Another effort to integrate human resource with CRM strategy was developing and holding a set of CRM training and learning programs. Systematic training or learning 
trends were posed as another successful critical factor to help customers to accept CRM innovations (Kim and Kim, 2009; Reinartz et al.; 2004).

Figure 4: Performance indexes (2005-2009)

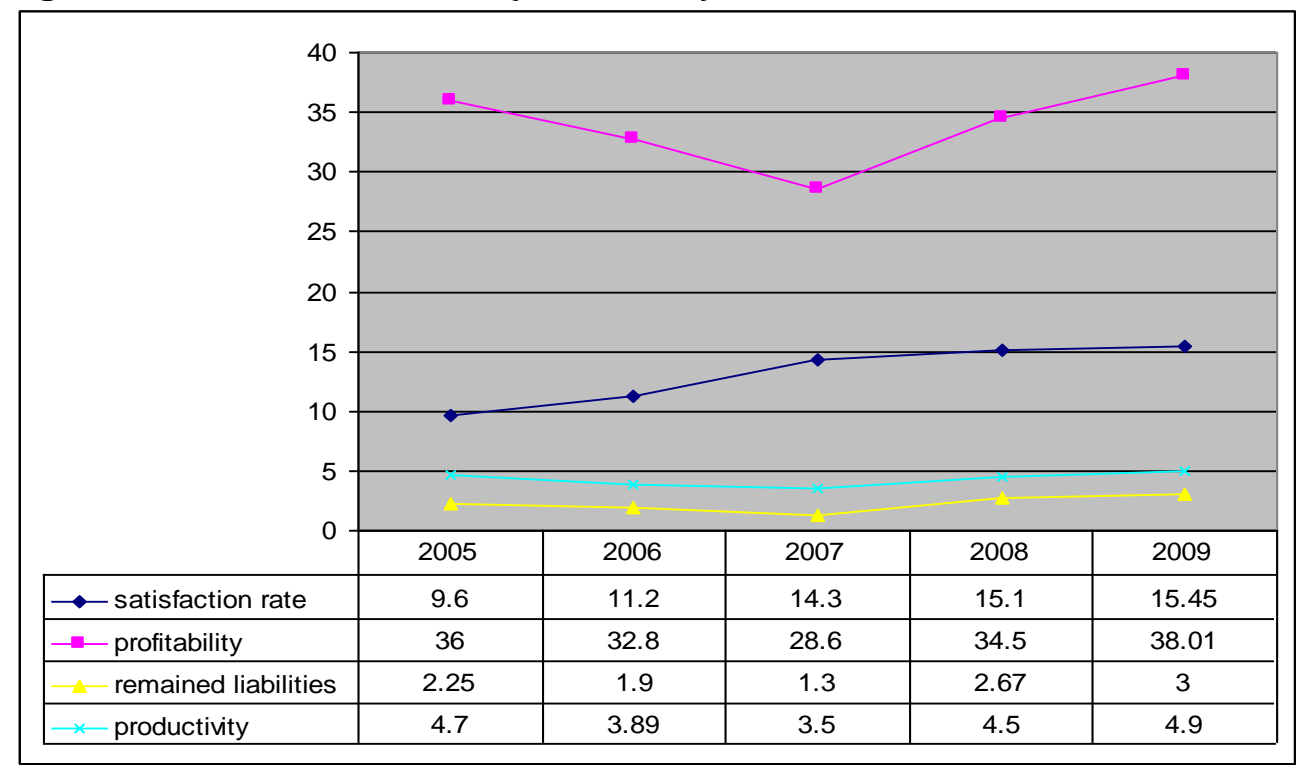

They followed to objectives: 1) They help to calm down imperative space of CRM implementation and 2) They prepare practical instructions to use of CRM-T system optimally. For first goal, a mediate-high-low method was taken by train plans. It means that they have prepared for intermediate managers at first and then they were propagated by them across the company. This method is better to promulgate sciencebased strategy similar to CRM across commercial organization (Nonaka, 1994) they tried to share concept, necessity and next instructions off CRM-T with all employees of main offices and branches through turnover and iterative trainings. For the latter, it was promoted as a formal turnover including regular and arranged training plans rather sole extensive and practical education. These educational plans allowed staff of CDB to understand the nature of new integrated resources and capabilities of CRM and this in turn helped them to share customer knowledge, daily decisions and improved performances. These kinds of measures to integrate human resources through allaying unsatisfied staff have aimed at changing understood viewpoint about CRM innovations besides accepting CRM-T. When staff of an organization is satisfied, they will pursue a positive approach in proportion to communicating with customers (Bendapudi and Leone, 2002; Donavan et al.; 2004; Shum et al.; 2008)Beyond capacities of an information system, individualized CRM strategy began to affect on acquisition and development of customers relations, which have been inactivated relatively, based on employee satisfaction and it was known that both productivity and profitability indicators have been grown (see fig. 8).

\section{Discussion and Conclusion}

Cooperative Development Bank is not the first organization where has embarked to implement an organizational CRM to improve its competition state; however this bank is interesting because has succeeded to modify and integrate its necessary resources and capabilities. The most important concept inferred from this study is that whenever CRM is considered as a technology implementing it successfully will be very difficult and even its successful implementations is not equal to strategy prosperity. Ravichandran and Lertwongstein (2005) support our claim. They emphasized that capability of an organization to use of IT to support its focal competences is depended on IS fundamental capabilities which are related to human resources, technology and IS department relations. Since it is not possible to apply all CRM measures to all organizations (Xu et al.; 2002), we believe that a company must select related capabilities and resources and then integrate them throughout the organization domain in order to outstand issues and needs prior to pose a CRM. Moreover, through combining organizational alignments proportional to CRM, which directs individuals to involve with critical resources and capabilities of CRM, an organization will be successful to improve organizational performance through CRM strategy. However, if CDB has taken initial resources and capabilities, which their integration was necessary for successful implementation of CRM, then present performance would have been occurred 
earlier. If we accept that the bank has expensed a great deal of money and time to meet the current competence, a clear lesson will be appeared to be learnt. It is true that they have not been satisfied with results of the first phase of implementation and tried to ameliorate the hidden opportunities gradually. Since CRM is a consecutive and permanent learning process rather an analytic method or information technology (Osarenkhoe, 2007), sit always must grow in order to meet changing needs of its customers permanently. Hence, a positive progress, which remains egocentric, albeit an invincible failure or little returns, is definitely one of the CRM cores, and CDB bank realized it as well.

Suggestions: the suggestions below are given with the hope to develop and deepen this part of the knowledge: Further suggestions for scholars:

- Doing exploration with the help of other qualitative strategies of the research.

- Conducting case studies about businesses created in the other areas such as insurance services.

- Applying the research findings to independent services and developing a comparative chance.

In addition to theoretical suggestions mentioned above, some practical suggestions are given for managers and policy-makers:

- Improving these aspects and criteria in integration of resources and capabilities to implement CRM case

- Supporting systems of in integration of resources and capabilities to implement CRM case of CDB

\section{References}

Pan, S. L., Tan, C. W. \& Lim, E. T. K. (2006). Customer relationship management (CRM) in egovernment: a relational perspective. Decision Support Systems, 42(1), 237-250.

Bendapudi, S. \& Leone, N. R. P. (2002). Managing B2B customer relationships following key contact employee turnover in a vendor firm. Journal of Marketing, 66(2), 83-101.

$\mathrm{Xu}$, Y., Yen, D., Lin, B. \& Chou, D. (2002). Adopting customer relationship management technology. Industrial Management \& Data Systems, 102(8), 442-452.

Brown, T. J., Mowen, J. C., Donavan, D. T. \& Licata, J. W. (2002). The customer orientation of service workers: personality trait effects on self and supervisor performance ratings. Journal of Marketing Research, 39(1), 110-119.

Chalmeta, R. (2006). Methodology for customer relationship management. The Journal of systems and software, 79(7), 1015-1024.

Donavan, D. T. \& Brown, T. J. \& Mowen, J. C. (2004). Internal benefits of service-worker customer orientation: job satisfaction, commitment, and organizational citizenship behaviors. Journal of Marketing, 68(1), 128-146.

Winer, R. S. (2001). A framework for customer relationship management. California Management Review, 43(4), 89-105.

Grant, R. M. (1991). The resource-based theory of competitive advantage: implications for strategy formulation. California Management Review, 33(3), 114-135.

Heskett, J. L., Jones, T. O., Loveman, G. W., Sasser, W. E. \& Schlesinger, L. A. (1994). Putting the serviceprofit chain to work. Harvard Business Review, 72(2), 164-174.

Kim, H. \& Kim, Y. (2009). A CRM performance measurement framework: Its development process and application. Industrial Marketing Management, 38(4), 477-489.

Kohli, R., Piontek, F., Ellington, T., VanOsdol, T., Shepard, M. \& Brazel, G. (2001). Managing customer relationships through E-business decision support applications: a case of hospital-physician collaboration. Decision Support Systems, 32(2), 171-187.

Luneborg, J. L. \& Nielsen, J. F. (2003). Customer-focused technology and performance in small and large banks. European Management Journal, 21(2), 258-269.

Mata, F. J., Fuerst, W. L. \& Barney, J. B. (1995). Information technology and sustained competitive advantage: a resource-based analysis. MIS quarterly, 19(4), 487-505.

Meltzer, M. (2001). A customer relationship management approach: integrating the call centre with customer information. Journal of database marketing, 8(3), 232-243.

Melville, N., Kraemer, K. \& Gurbaxzni, V. (2004). Review: information technology and organizational performance: an integrative model of IT business value. MIS Quarterly, 28(2), 283-322.

Nonaka, I. (1994). A dynamic theory of organizational knowledge creation. Organization Science, 5(1), 1437.

Osarenkhoe, A. \& Bennani, A. (2007). An exploratory study of implementation of customer relationship management strategy. Business Process Management Journal, 13(1), 139-164. 
Park, C. \& Kim, Y. (2003). A framework of dynamic CRM: linking marketing with information Strategy. Business Process Management Journal, 9(5), 652-671.

Peppard, J. (2000). Customer relationship management (CRM) in financial services. European Management Journal, 18(3), 312-327.

Peppard, J. \& Ward, J. (2004). Beyond strategic information systems: towards an IS capability. The Journal of Strategic Information Systems, 13(2), 167-194.

Ravichandran, T. \& Lertwongsatien, C. (2005). Effect of information systems resources and capabilities on firm performance: a resource-based perspective. Journal of management information systems, 21(4), 237-276.

Ray, G., Muhanna, W. A. \& Barney, J. B. (2005). Information technology and the performance of the customer service process: a resource-based analysis. MIS Quarterly, 29(4) 625-652.

Reinartz, W. J., Krafft, M. \& Hoyer, W. D. (2004). The customer relationship management process: its measurement and impact on performance. Journal of Marketing Research, 41(3), 293-305.

Rigby, D. K. \& Ledingham, D. (2004). CRM done right. Harvard Business Review, 82(11), 118-129.

Santhanam, R. \& Hartono, E. (2003). Issues in linking information technology capability to firm performance. MIS quarterly, 27(1), 125-154.

Shum, P., Bove, L. \& Auh, S. (2008). Employees' affective commitment to change: the key to successful CRM implementation. European journal of marketing, 42(11/12), 1346-1371.

Speier, C. \& Venkatesh, V. (2002). The hidden minefields in the adoption of sales force automation Technologies. Journal of Marketing, 66(3), 98-111.

Wind, Y. \& Saaty, T. L. (1980). Marketing applications of the analytic hierarchy process. Management Science, 26(7), 641-658.

Fletcher, K. \& George, W. (1995). Organizational, strategic and technical barriers to successful implementation of database marketing. International Journal of Information Management, 15(2), 115-126.

Hwang, Y. \& Kim, D. J. (2007). Customer self-service systems: the effects of perceived Web quality, with service contents on enjoyment, anxiety, and e-trust. Decision Support Systems, 43(3), 746-760.

Kim, Y. (2006). Toward a successful CRM: variable selection, sampling, and ensemble. Decision Support Systems, 41(2), 542-553.

Kim, E. \& Lee, B. (2007). An economic analysis of customer selection and leveraging strategies in a market where network externalities exist. Decision Support Systems, 44(1), 124-134.

Donavan, D. T., Brown, T. J. \& Mowen, J. C. (2004). Internal benefits of service-worker customer orientation: job satisfaction, commitment, and organizational citizenship behaviors. Journal of Marketing, 68(1), 128-146.

Kulp, S. C., Lee, H. L. \& Ofek, E. (2004). Manufacturer benefits from information integration with retail customers. Management science, 50(4), 431-444.

Maxham, J. G. \& Netemeyer, R. G. (2003). Firms reap what they sow the effects of shared values and perceived organizational justice on customers' evaluations of complaint handling. Journal of Marketing, 67(1), 46-62.

Meyer, M. \& Kolbe, L. M. (2005). Integration of customer relationship management: status quo and implications for research and practice. Journal of Strategic Marketing, 13(3), 175-198.

Reid, A. \& Catterall, M. (2005). Invisible data quality issues in a CRM implementation. Database Marketing \& Customer Strategy Management, 12(4), 305-314.

Rigby, D. K. \& Ledingham, D. (2004). CRM done right. Harvard Business Review, 82(11), 118-129.

Rowley, J. (2002). Eight questions for customer knowledge management in e-business. Journal of Knowledge Management, 6(5), 500-511.

Speier, C. \& Venkatesh, V. (2002). The hidden minefields in the adoption of sales force automation Technologies. Journal of Marketing, 66(3), 98-111.

Teo, T. S. H., Devadoss, P. \& Pan, S. L. (2006). Towards a holistic perspective of customer relationship management (CRM) implementation: a case study of the Housing and Development Board, Singapore. Decision Support Systems, 42(3), 1613-1627.

Verhoef, P. C. (2003). Understanding the effect of customer relationship management efforts on customer retention and customer share development. Journal of Marketing, 67(4), 30-45. 